\title{
KULTURNE TERASE V SLOVENSKIH POKRAJINAH
}

\author{
mag. Helena Križaj Smrdel \\ Hotemaže 67 b, SI-4205 Preddvor \\ e-mail: helena.krizaj-smrdel@guest.arnes.si
}

Izvirni znanstveni članek

COBISS 1.01

\section{Izvleček}

Kulturne terase so eden najvidnejših antropogenih posegov v relief, ki bogatijo pokrajinsko sliko dobršnega dela Slovenije. Na podlagi obsežne terenske raziskave so bili opredeljeni tipi kulturnih teras. Ločimo stare, tradicionalne kulturne terase (istrski, brkinski in dolenjski tip) in nove, sodobne, predvsem vinogradniške terase, ki so si zaradi strojnega urejanja podobne in ponekod predstavljajo nove terasirane pokrajine.

Ključne besede: kulturna terasa, terasirana pobočja, terasirana pokrajina, Slovenija

\section{CULTURAL TERRACES IN SLOVENIAN REGIONS}

\begin{abstract}
Cultural terraces are one of the most outstanding anthropogenic interventions in the Earth surface caused by the agrarian activity. Also in Slovenia they have reshaped many landscapes in the Sub-Mediterranean and the Sub-Pannonian Slovenia as well as in the Dolenjska Region. In general, we distinguish between old traditional cultural terraces which differ form a province to province so they are further differentiated into the Istrian, Brkini and Dolenjska type of terraces, and new modern mostly vinegrowing terraces, which are similar to one another due to the use of machines in their construction and in some places they represent real terraced areas.
\end{abstract}

Key words: cultural terrace, terraced slopes, terraced landscape, Slovenia 


\section{UVOD}

Slovenija slovi po reliefno raznolikih pokrajinah, številnim med njimi pa so dodale poseben pečat kulturne terase. V prispevku so obravnavane kulturne terase $\mathrm{v}$ tistih slovenskih pokrajinah, kjer so tako razširjene, da jih lahko označimo kot terasirane pokrajine. Čeprav je pojem kulturna terasa splošno poznan in uporabljen, pa v slovenski strokovni literaturi še ni bil temeljiteje obdelan, posebno še $z$ vidika njegove pokrajinske funkcije.

Glavni namen razprave zato ni le prikazati pomena kulturnih teras, ampak predvsem različnost kulturnih teras v slovenskih pokrajinah, ker so nastale zaradi različnih naravnih, gospodarskih in kulturnih razmer. Z raziskavo smo želeli preveriti, v kolikšni meri lahko govorimo o tipih teras, ki naj bi bile odraz pokrajinskih svojstvenosti. Razprava pa poleg razlik med kulturnimi terasami skuša opozoriti tudi na njihov življenjski ritem, ki je del spreminjajočega se geografskega okolja in procesov v njem. Različni družbenogeografski vzroki in demografske spremembe v pokrajinah so namreč vzrok za nenehno spreminjanje terasiranih pokrajin. Te namreč ponekod doživljajo razcvet, drugod pa zaradi opuščanja obdelave propadajo; zadnje velja za stare, tradicionalne kulturne terase. Najlepše primere takih teras bi bilo potrebno zaščititi kot del kulturne dediščine in jih tako rešiti propadanja.

\section{I.I. Kulturne terase}

Kulturne terase so reliefne stopničaste oblike v nagnjenem reliefu, ki jih je človek izoblikoval z namenom, da bi pridobil ravno kmetijsko površino, preprečil erozijo prsti in ohranil talno vlažnost na terasah. Izraz kulturna terasa označuje dejstvo, da je takšna terasa namenjena gojitvi kulturnih rastlin, zato jih lahko imenujemo tudi obdelovalne terase. Drug izraz za kulturne terase so antropogene terase kot odraz človekovega dela v nasprotju z naravnimi rečnimi terasami. Urejanje kulturnih teras je zelo zahtevno. V preteklosti so jih urejali ročno, danes samo še strojno. V nekaterih slovenskih pokrajinah za kulturne terase obstajajo domači izrazi. Na Koprskem, v Vipavski dolini in na Krasu jih imenujejo paštni.

Kadar se kulturne terase nizajo po celotnem pobočju, govorimo o terasiranih pobočjih, kjer pa terasirana pobočja $\mathrm{v}$ pokrajini popolnoma prevladujejo, govorimo o terasirani (terasni, terasasti) pokrajini; najlepša primera takšnih pokrajin v Sloveniji so Goriška brda in Jeruzalemske gorice.

Kulturna terasa je sestavljena iz dveh delov: iz ravnega dela (terasne police, ploskve ali površine) in iz strmega dela (ježe oziroma brežine terase). V različnih slovenskih pokrajinah za ta dva dela uporabljajo različna imena, npr. v Brkinih strmemu delu terase rečejo korona, na Dolenjskem meja ali omejek, na Koprskem pa škarpa ali brežina, če je terasa podzidana, pa zid.

Na strmi del teras vpliva kamninska sestava. V flišni Istri so ježe teras narejene iz trdnega peščenjaka, ki sestavlja flišne plasti, v Brkinih, na Dolenjskem in v Obpanonski Sloveniji pa so vse zemljate in zatravljene. Oblika in velikost ježe terase pa nista odvisni le od sestave tal, ampak tudi od naklona pobočja. Večji je naklon, višja je ježa terase.

Druga dva elementa, ki sestavljata kulturne terase, sta naklon škarpe in naklon terasne police. Terasna polica je lahko ravna, nagnjena navzven ali navznoter proti pobočju. Z vi- 
dika urejanja teras so najenostavnejše terase z vodoravnimi terasnimi ploskvami ali blagim nagibom proti pobočju.

\section{I.2. Dosedanje raziskave kulturnih teras v Sloveniji}

Čeprav so kulturne terase pomembna poteza dobršnega dela slovenskih pokrajin, so bile v slovenski geografiji dolgo časa prezrte. Izjema je delo Titla (1965), ki je temeljito preučil kulturne terase na Koprskem, tako po gradbenih značilnostih kot po rabi tal v obdobju od franciscejskega katastra do 60. let 20. st. Belec (1965) in Bračič (1967) sta v monografijah o Ljutomersko-Ormoških goricah in Vinorodnih Halozah obravnavala kulturne terase kot nov pokrajinski element. Kulturne terase so v novejših objavljenih delih večkrat omenjene predvsem kot pokrajinski element, kjer prihaja do pospešenega zatravljanja njivskih površin in zaraščanja (Plut 1977; Kladnik 1990,). Več pozornosti pa je kulturnim terasam namenjeno od konca 20. st. dalje. Drobnjak (1990) je izdelal tipologijo teras glede na značilnosti terasne ploskve in ježe teras. Najbolj poglobljeno in celovito pa so obravnavane značilnosti kulturnih teras v Goriških brdih (2008), delo skupine strokovnjakov z Geografskega inštituta Antona Melika ZRC SAZU in Fakultete za arhitekturo. Raziskava je bila opravljena v okviru projekta Alpter kot del prizadevanj po spoznavanju in prevrednotenju kulturnih teras v alpskem prostoru.

\section{I.3. Metodologija dela}

Raziskava je izrazito temeljila na terenskem delu. Pregledu ugotovitev o kulturnih terasah v strokovni literaturi je sledil obsežen ogled tistih pokrajin, kjer so obsežnejša območja s kulturnimi terasami. Na večkratnih ogledih je nastala obsežna fototeka, hkrati pa tudi odločitev o vzorčnih območjih, na katerih so bile kulturne terase temeljito preučene. Sledila je priprava metodologije za ugotavljanje značilnosti kulturnih teras, ki naj bi omogočila opredelitev njihovih posebnosti oziroma razlik med pokrajinami (ekspozicija, naklon pobočja, širina in značilnosti terasne ploskve, višina ježe, raba tal itd.). Na podlagi izmer na terenu so bile izdelane skice. Na terenu so bili opravljeni številni pogovori z domačini in s kmetijskimi strokovnjaki, ki so omogočili poglobljen vpogled v značilnosti in funkcijo kulturnih teras.

Srž raziskovalnega dela je bila usmerjena na 17 izbranih vzorčnih območij, ki so bila določena po obsežnem pregledu terena, pogovorih z domačini in študiju literature. V posameznih pokrajinah sta bili praviloma izbrani dve vzorčni območji, eno s starimi in eno z novimi terasami.

\section{KULTURNE TERASE V SLOVENSKIH POKRAJINAH}

Pestrost naravnih razmer, različen zgodovinski razvoj in kulturna raznolikost slovenskih pokrajin je prvotno usmerila raziskavo le na eno območje, a je ravno pokrajinska pestrost/ raznolikost preusmerila zasnovo raziskave v iskanje odgovora na vprašanje: ali se in kako se 
omenjena pestrost kaže tudi $\mathrm{v}$ značaju kulturnih teras. To je postalo temeljno raziskovalno vprašanje, ki je vodilo celotno delo.

Slika 1: Vzorčna območja preučevanja kulturnih teras v slovenskih pokrajinah

Figure 1: Sample landscapes comprised in the study of cultural terraces in Slovenian regions

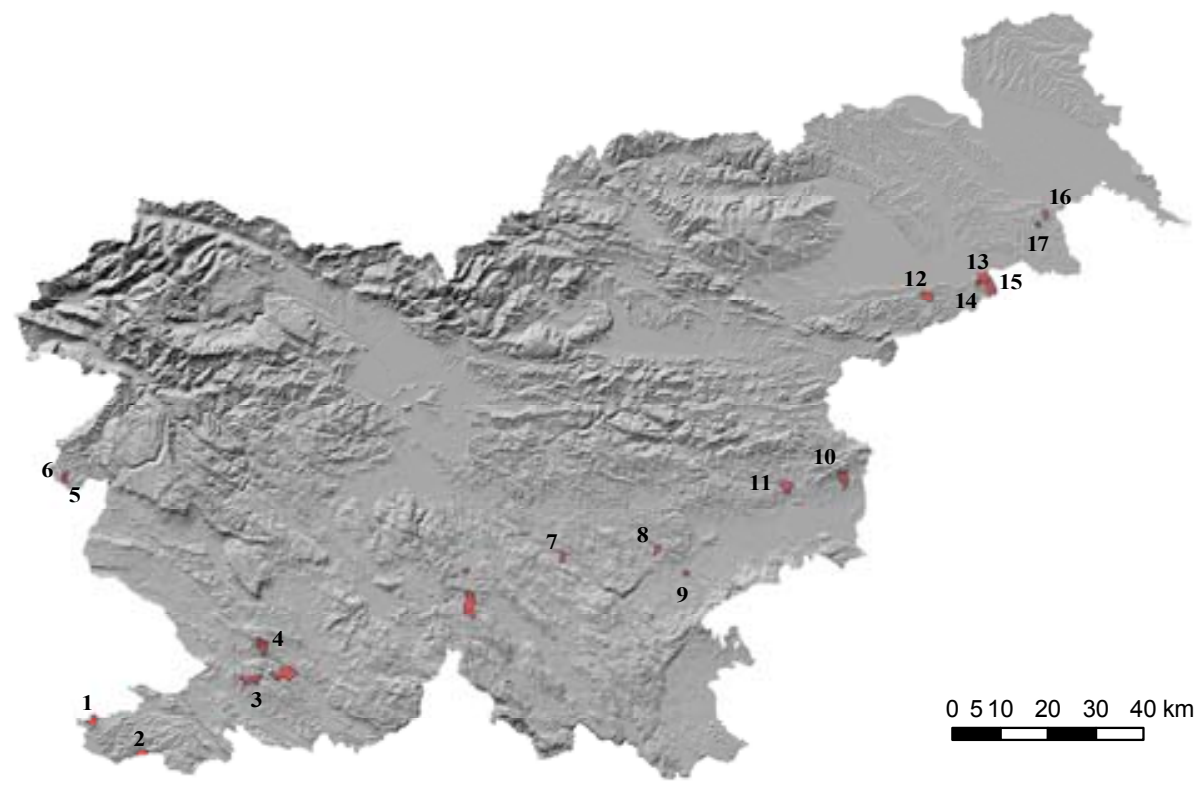

Obmediteranska Slovenija:

Koprsko primorje: 1 Strunjanski zaliv, 2 posestvo Brič,

Brkini: 3 Artviže, Ostrovica, 4 Ostrožno Brdo

Goriška brda: 5 kmetija Toroš, 6 kmetija Čarga

Dolenjska: 7 Šmihel pri Žužemberku, 8 Dolenje Karteljevo, 9 Petelinjek

Obpanonska Slovenija: $\quad$ Bizeljsko-Sremiške gorice: 10 Pišece, 11 Sremič

Haloze: 12 Podlehnik, 13 Hrastovec, 14 Belski vrh, 15 Turski vrh

Slovenske gorice: 16 Slamnjak, 17 Jeruzalem

\section{I. Kulturne terase $v$ Koprskem primorju}

Kulturne terase so tradicionalna oblika obdelave zemlje v Koprskem primorju, zato so med najvidnejšimi antropogenimi elementi v pokrajini. Domačini jih imenujejo paštni. Njihov nastanek je povezan z mehkimi flišnimi kamninami in padavinami v obliki nalivov, ki so povzročali močno erozijo prsti. Poleg preprečevanja erozije pa pomembno zadržujejo tudi talno vlažnost na terasnih policah. Tu se namreč akumulira precej vlage, ki v rastni dobi ublaži poletno sušo. Ježo terase, poraslo s travo, domačini imenujejo brežina, podzidano pa zid. $\mathrm{V}$ preteklosti so bile terase narejene ročno za intenzivno kmetovanje in gojenje kulturnih rastlin; graditi naj bi jih začeli že Rimljani. Z naraščanjem števila prebivalcev 
in večanjem potreb po hrani so začeli terasirati pobočja. Ostanek takega načina obdelave zemlje je izolski amfiteater, polkrožna terasirana pobočja nad Izolo, kjer terase zaradi opuščanja kmetovanja danes propadajo. Vse do konca 19. st. so bile ježe teras kamnite ali zidane. Za zid so uporabljali bloke peščenjaka, ki so ga dobili v flišu. Kasneje so začeli urejati robove teras s travnimi brežinami, katerih vzdrževanje je bilo cenejše od kamnitih zidov. Danes so kamniti zidovi redkost. Stare, tradicionalne kulturne terase pa se razlikujejo tudi po širini terasne police. Čim manjši je bil nagib pobočja, širše so bile terasne police in obratno. Dolge in široke terasne police so se ohranile na vrhu slemen, terase z ožjimi in krajšimi policami, ki so nastajale na strmejših pobočjih, pa so večinoma propadle ali jih je prerastel gozd.

Titl (1965) deli kulturne terase tudi po nadmorski višini in po kulturnih rastlinah, ki so jih gojili na terasah. Razlikuje vinogradniško-poljedelske terase, sadjarsko-vrtnarske in čiste vrtnarske terase. Vinogradniško-poljedelske terase so bile večinoma njive s trto na brežini. Gre za staro obliko terasnega nasada pred pojavom filoksere. Sadjarsko-vrtnarske terase so bile razširjene v južnih legah in namenjene pridelavi zgodnje zelenjave in sadja, predvsem češenj. Čiste vrtnarske terase so nastale ob koncu 19. st. zaradi velikega povpraševanja po zgodnji zelenjavi, predvsem na bližnjem tržaškem trgu. V drugi polovici 20. st. so začeli urejati čiste vinogradniške in čiste sadjarske terase. Narejene so strojno in predstavljajo moderne terasne vinograde. Nastajajo pa tudi novi oljčni terasni nasadi.

Slika 2: Star, tradicionalen oljčni nasad z ravnimi terasnimi policami in kamnitimi škarpami v Strunjanskem zalivu (foto: H. Križaj Smrdel)

Figure 2: An old traditional olive tree plantation with plain terrace ledges and stone walls in the Bay of Strunjan (photo: H. Križaj Smrdel)

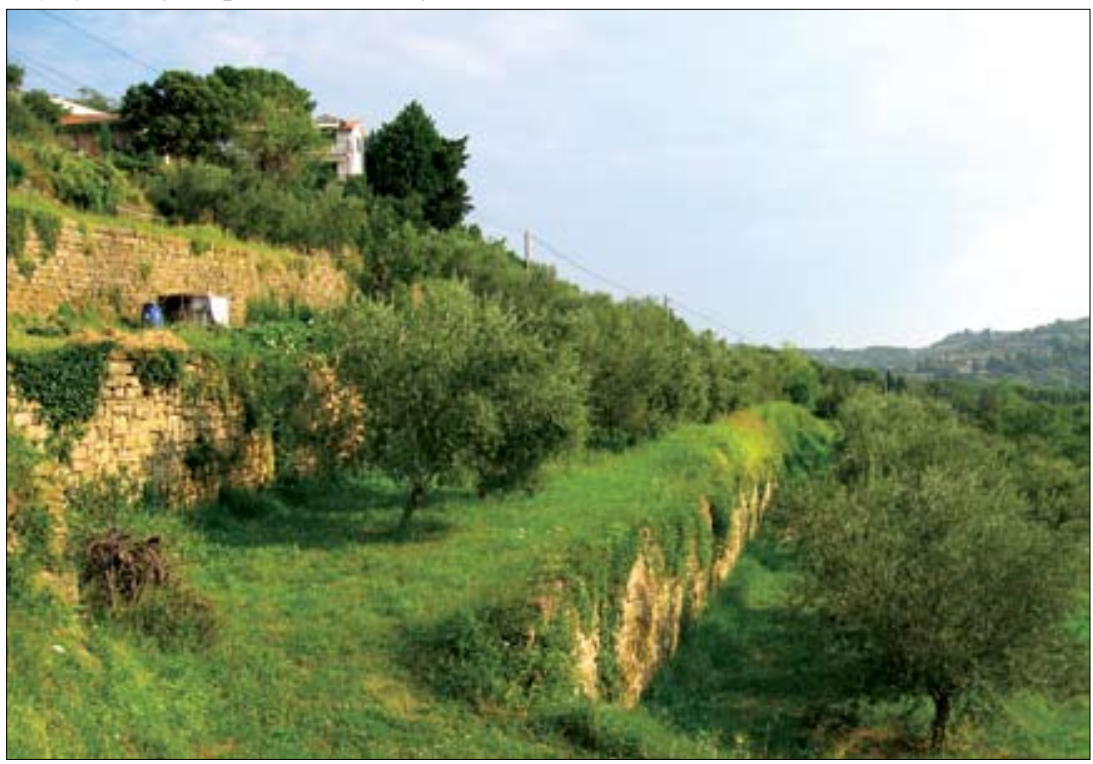


Slika 3: Skica starih, tradicionalnih kulturnih teras $v$ Strunjanskem zalivu

Figure 3: A sketch of old traditional terraces in the Bay of Strunjan

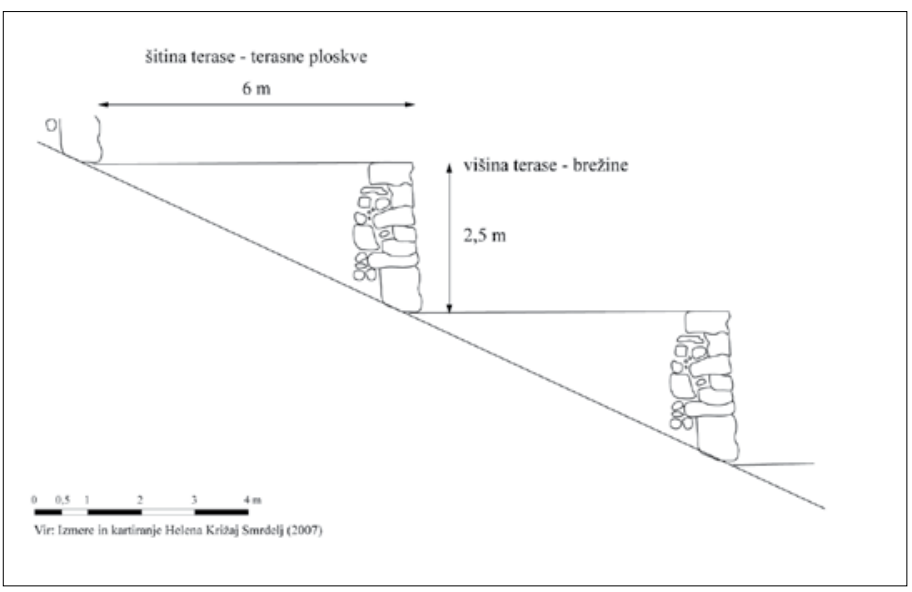

Preglednica 1: Meritve teras v starem, tradicionalnem, terasnem oljčnem nasadu Table 1: Characteristics of terraces in old, traditional olive tree plantation

\begin{tabular}{|l|l|}
\hline Lokacija & $\begin{array}{l}\text { Levo od Strunjanskega zaliva, na vzhodnem pobočju pod magistralno } \\
\text { cesto Strunjan-Portorož }\end{array}$ \\
\hline Nadmorska višina & do $10 \mathrm{~m}$ \\
\hline Ekspozicija & vzhodna \\
\hline Naklon pobočja & $25^{\circ}$ \\
\hline Značilnost terasne površine & ravna \\
\hline Širina terasne površine & od 6 do $6,5 \mathrm{~m}$ \\
\hline Značilnosti ježe & kamnita škarpa, zid je iz peščenjaka, ponekod razpada \\
\hline Višina ježe & od 2 do $2,6 \mathrm{~m}$, raven zid, delan ročno brez veziva \\
\hline Starost teras & stare, tradicionalne, več 100 let \\
\hline Raba tal na terasah & star oljčni nasad \\
\hline Ogroženost & kamniti zidovi se ponekod podirajo, rušijo, ni znakov obnavljanja \\
\hline
\end{tabular}

Vir/Source: Izmere in kartiranje Helena Križaj Smrdel (31.7.2008)

Za vzorčni primer novega vinogradniškega terasnega nasada navajam posestvo Brič ob slovensko-hrvaški meji v krajinskem parku Dragonja. Edinstvena lega na vrhu slemena omogoča, da so vsa pobočja terasirana, tako prisojna kot osojna. Posebnost je del vinograda, ki so ga uredili po vzorcu starih istrskih teras. Terase so podprli z zidanimi škarpami, ki so zgrajene iz kamnitih blokov peščenjaka, tako kot je bilo značilno za staro, ročno gradnjo istrskih teras. Posestvo Brič je tako primer, kako lahko s tradicionalnim načinom obdelave zemlje pridelamo visoko kakovostna vina. 
Novi terasni nasadi so nadomestili stare, tradicionalne, ki vse bolj propadajo in izginjajo. Eden takih, ki še kljubuje času, je star oljčni nasad v Strunjanskem zalivu, kjer so terasne police podprte $\mathrm{z}$ več kot dva metra visokimi kamnitimi škarpami. Na tem primeru je prikazana metodologija dela: za vsako vzorčno območje je bila izdelana skica teras, preglednica z merskimi značilnostmi teras in njihovo rabo ter fotografija območja.

\subsection{Kulturne terase v Goriških brdih}

Pokrajinski videz Goriških brd zagotovo najbolj zaznamujejo kulturne terase, zato so Goriška brda najbolj izrazita terasirana pokrajina v Sloveniji. To je še posebno značilno za južni oziroma spodnji del Brd, ki je monokulturno usmerjen v vinogradništvo. Zanimiv je domač izraz za teraso, brajda, ki je obrobljena z grivo, ježo teras, ki so jo nekoč tudi obzidali. Pozneje je bila griva navadno travnata in zasajena s sadnim drevjem. Na Goriškem je ljudski izraz za terasni vinograd ronek (Kladnik 1990).

Slika 4: Obročkanje kot posebna oblika terasnega nasada v Goriških brdih (foto: H. Križaj Smrdel) Figure 4: Ring shaping as a special form of a terraced plantation in Goriška brda (photo: H. Križaj Smrdel)

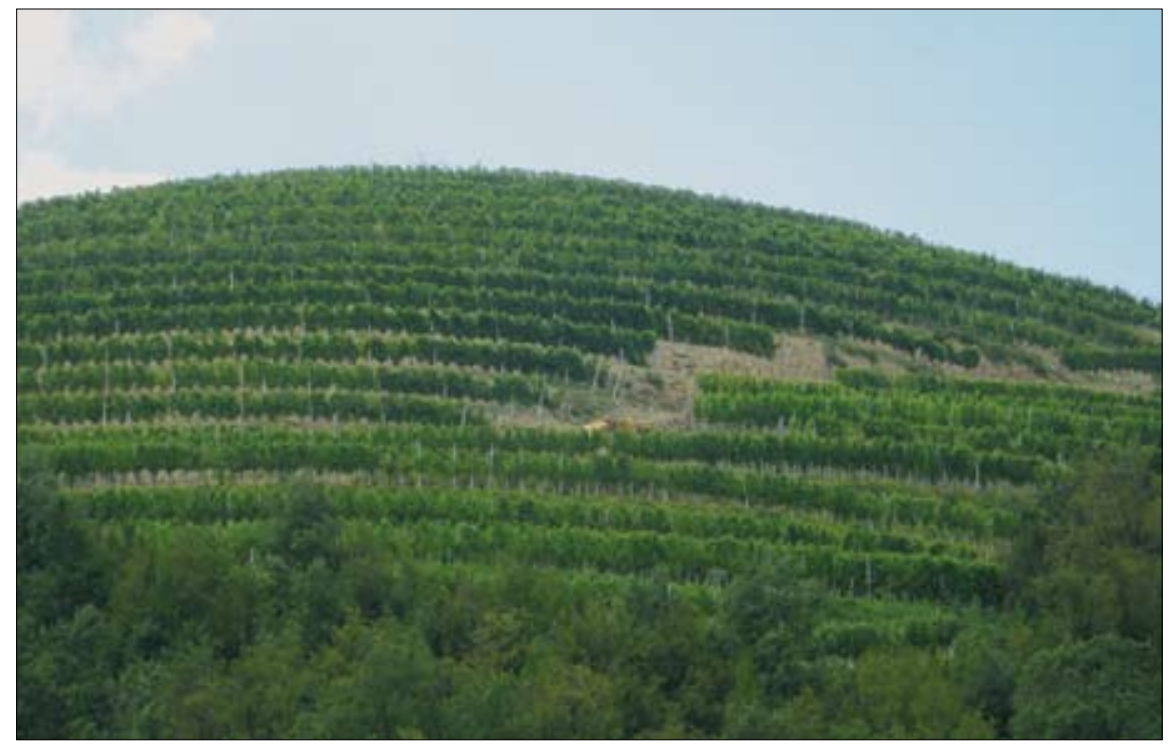

Gradnja kulturnih teras je bila tudi v Goriških brdih obvezna oblika urejanja kmetijskih površin, saj je na poroznem flišu močna erozija prsti, pobočja pa so dokaj strma. Zgodovina urejanja teras tudi v Brdih sega v rimski čas. V zgodovini sta bila v vinorodnih Goriških brdih ponudba in povpraševanje po vinu močno povezana $z$ gradnjo ali opuščanjem kulturnih teras. Do druge svetovne vojne so terase v Goriških brdih urejali in vzdrževali ročno. Širine in višine teras so bile zato različne. Brežino teras so utrjevali z zidom iz kamenja, ki so ga 
otrebili na pobočju, ko so čistili teren za pripravo teras. Neenake so bile tudi dolžine terasnih polic, na kar je vplivala zemljiška razdelitev. Po drugi svetovni vojni so začeli urejati terase strojno, predvsem z bagri in buldožerji. Strojna mehanizacija je omogočala, da so pri pripravi pobočja za terasiranje najprej celotno nagnjeno površino poravnali, s čimer so na večjem delu pobočja dobili enakomeren nagib. V poravnano pobočje so nato vrezali terase. Te so bile zaradi strojnega dela med seboj enake po terasni ploskvi in terasni brežini. Za vinsko trto so uredili enovrstne, dvovrstne in večvrstne terase. Pokrajinski videz Goriških brd predstavljajo danes večvrstne vinogradniške terase. Kot vzorčna primera preučevanja kulturnih teras so bili izbrani terasni vinogradi na dveh več sto let starih briških kmetijah, ki se ponašata $\mathrm{z}$ dolgoletno tradicijo vinogradništva in vinarstva, in sicer kmetija Čarga v bližini Dobrovega in kmetija Toroš južno od Medane.

Na kmetiji Čarga prevladujejo novi, strojno urejeni terasni enovrstni vinogradi. Ježe teras, ki so vse zemljate in zatravljene, so visoke od enega do dva metra, terasne police pa široke od štiri do pet metrov. Kmetija je zanimiva še po posebnem tipu terasiranja pobočij, t. i. obročkanju, pri katerem se terase vrstijo v nizu plastnic okoli hriba, kjer zajame terasiranje vse ekspozicije. Zaradi enako visokih brežin in širin teras deluje terasni vinograd skladno in zelo urejeno. Izjema je najnovejši del vinograda na severni strani griča z naklonom $70^{\circ}$. Gre za nadpovprečno strm vinograd, ki so ga uredili z izsekavanjem gozda. Strojna obdelava je zaradi velike strmine tvegana in nevarna. Veliko povpraševanje po vinu in dober zaslužek pa sta vzrok, da se vinogradi vse bolj širijo v strme in severne predele gričev, ki se tako spreminjajo v nova terasirana pobočja.

Kmetija Toroš v bližini Medane leži v južnem delu Goriških brd sredi izrazito terasirane pokrajine. Način obdelave zemlje je že od nekdaj vezan na kulturne terase. Te so v preteklosti hodili ročno kopat Furlani. Danes na kmetiji prevladujejo večvrstni terasni vinogradniški nasadi. Gre za dvo- in štirivrstne vinogradniške terase, ki se prilagajajo strmini in naklonu pobočja, zato se razlikujejo po širini in višini ježe. Ekspozicije so prisojne, največkrat južne in jugozahodne. Čeprav gre za stare vinogradniške terase, je vinogradniški kompleks lepo oskrbovan in obdelan, saj se kmetija ukvarja tudi s kmečkim turizmom.

\subsection{Kulturne terase $\mathbf{v}$ Brkinih}

Brkini so prehoden svet med primorskimi in notranje celinskimi pokrajinami. Kot pokrajinska posebnost jih odlikuje flišno hribovje s podolgovatimi in strnjenimi naselji na vrhu slemen. Značilen antropogeni vpliv v pokrajini so kulturne terase. Slemena in pobočja brkinskih hribov so spremenjena v kulturne terase; največ jih je na območju zahodnih in osrednjih Brkinov v okolici vasi Artviže, Ostrovica, Vatovlje, Misliče, Mrše in na Ostrožnem Brdu. Posebnost brkinskih teras je, da so zemljate, kar pomeni, da so strmi deli teras iz zemlje in zatravljeni. Terasne police so običajno precej široke, po vrhu slemen tudi do 8 metrov in so bile namenjene njivam. Prav v tem se bistveno razlikujejo od ozkih primorskih teras in zato bolj spominjajo na značilnosti kulturnih teras v notranji Sloveniji. Tudi domačini radi poudarjajo, da so njihove terase drugačne od istrskih ali kraških. Druga posebnost brkinskih teras je v tem, da na ježah teras, ki jih tukaj imenujejo korone, pogosto nasadijo sadno drevje, posebno češnje in češplje. $S$ tem utrdijo robove teras in preprečijo erozijo, sadno drevje 
pa dobi več svetlobe. Sadnega drevja je lahko med parcelami ali na robovih teras toliko, da ustvarjajo videz sadovnjaka.

Brkinske terase so stare, po ocenah domačinov 200 in več let. Delali so jih ročno, tako da so najprej skopali strmi del, nato pa z izkopanim materialom nasuli polico oziroma teras-no ploskev. Terase so gradili v zimskem času, ko ni bilo dela na poljih, najverjetneje s pomočjo sezonske delovne sile, ki je prihajala iz sosednjih hrvaških krajev; prilagajajo se naklonom površja in ekspoziciji. Ker gre za stare, tradicionalne terase, se širina terase in višina ježe oziroma korone zaradi različnih strmin razlikujeta. Čim višji je naklon pobočja, tem višje so tudi korone teras, ožje pa so terasne police. Pri velikih naklonih so lahko ježe teras visoke do 5 metrov.

Danes je velika večina brkinskih teras zatravljenih, zaradi opuščanja kmetovanja pa tudi propadajo in se zaraščajo. Le še redke terase, običajno na vrhu slemen v bližini vasi, kjer je svet bolj položen, so izkoriščene za njive. Kulturne terase na najbolj strmih in osojnih pobočjih so opuščene in jih že prerašča gozd. Vzrok za propadanje kulturnih teras je opuščanje obdelave zemlje in odseljevanje prebivalstva. Brkini so namreč demografsko ogrožena pokrajina; zaradi ostarelosti prebivalstva nekatere vasi celo propadajo. Zaradi goste agrarne poseljenosti v preteklosti in s tem velike potrebe po hrani, ki so jo zaradi strmega terena morali pridelati na terasah, je bil tak način obdelave zemlje takrat nujen in smotrn. Danes se je način življenja spremenil in kmetijska zemljišča na terasah se vse bolj zaraščajo in propadajo. Zato je razumljivo, da v Brkinih ne najdemo novih, sodobnih terasnih nasadov. Kot vzorčna primera preučevanja kulturnih teras v Brkinih so bila izbrana območja vasi Artviže in Ostrovica ter Ostrožno Brdo.

Vzorčno območje Artviže-Ostrovica obsega dolga terasirana pobočja od cerkvice Sv. Socerba nad vasjo Artviže, ki predstavlja z nadmorsko višino 817 m najvišjo točko Brkinov, do vasi Ostrovica. Okolica obeh brkinskih vasi je preobražena s kulturnimi terasami, ki predstavljajo tipične brkinske poljedelske terase. Po vrhu slemena pred vasjo Artviže prevladujejo od 5 do $8 \mathrm{~m}$ široke poljedelske terase. Nekaj njiv je v bližini vasi, večina teras, ki se nizajo po prisojnih pobočjih dlje od vasi, pa je namenjena košnji. Te terase imajo ožje terasne police, v povprečju dva metra, ježe teras so vse zatravljene in prilagojene naklonu. Takšno izredno lepo in 200 metrov dolgo terasirano pobočje je na vzhodnem pobočju med Artvižami in Ostrovico. Kulturne terase na območju vasi Ostrovica pa so tipične brkinske terase s sadnim drevjem na koronah. Terasne police so široke od 4 do 8 metrov, a na žalost vsako leto manj obdelane. Vas Ostrovica ima le še pet hiš in deset prebivalcev (Gašperič 2009).

Drugo vzorčno območje v Brkinih predstavljajo kulturne terase na Ostrožnem Brdu. Vas leži na severnem robu Brkinov na vrhu slemena na nadmorski višini $632 \mathrm{~m}$. Pod vasjo se po obsežnem vzhodnem pobočju razteza eno najlepših in najdaljših terasiranih pobočij v Brkinih. V preteklosti so na prisojnih pobočjih pod slemeni izsekali gozd in si uredili polja v obliki kulturnih teras. Terasirana pobočja okoli vasi so omogočala intenzivno pridelavo hrane in preprečila erozijo prsti. Danes se vse več obdelovalnih površin na kulturnih terasah zarašča. Na Ostrožnem Brdu se izgublja značilen terasast izgled pokrajine. Ježe teras zarašča grmovna in drevesna vegetacija. Njive na terasah so se ohranile le na najbolj ravnih terenih in na vrhu slemen. 
Zanimiva je primerjava kulturne pokrajine na Ostrožnem Brdu leta 1817 po franciscejskem katastru in danes. Ugotovila sem, da sprememba rabe tal močno vpliva na izgled tradicionalne, terasirane pokrajine na Ostrožnem Brdu. Leta 1817 so na terasah prevladovale njive, terase so bile lepo vzdrževane in obdelane. Veliko je bilo tudi travnikov in pašnikov, zelo malo pa gozda. Po 200 letih sta množično odseljevanje in pomanjkanje delovne sile vzrok za opuščanje kmetijske zemlje, s tem pa tudi za počasno propadanje terasne pokrajine. Njive so le še redke, namesto njih prevladujejo travniki, močno je napredoval gozd. Opuščanje obdelovanja zemlje povzroča propadanje teras in če se bo proces nadaljeval, bo propadla tradicionalna terasasta pokrajina, tako značilna za Ostrožno Brdo. Rešitev vidim v sonaravnem kmetovanju, namenjenem pridelavi zdrave ekološko pridelane hrane, po kateri je veliko povpraševanje. Potrebni bi bili novi razvojni programi podeželja, ki bi motivirali mlade ljudi, da bodo ostali na podeželju. Alternativa je tudi okolju prijazen turizem, pohodništvo in kolesarjenje. Vse to bi lahko preprečilo propadanje kulturne pokrajine, s tem pa tudi kulturnih teras, ki še ostajajo najbolj viden antropogeni element v Brkinih in na Ostrožnem Brdu.

Slika 5: Terasirano pobočje pod vasjo Ostrožno Brdo je eno najlepših v Brkinih. Na koronah teras se kaže zaraščanje z grmovnim in drevesnim rastjem (foto: H. Križaj Smrdel)

Figure 5: A terraced hillside at the foot of the village Ostrožno Brdo is one of the most beautiful in Brkini. The sloping parts of terraces are overgrown with shrubs and trees (photo: H. Križaj Smrdel)

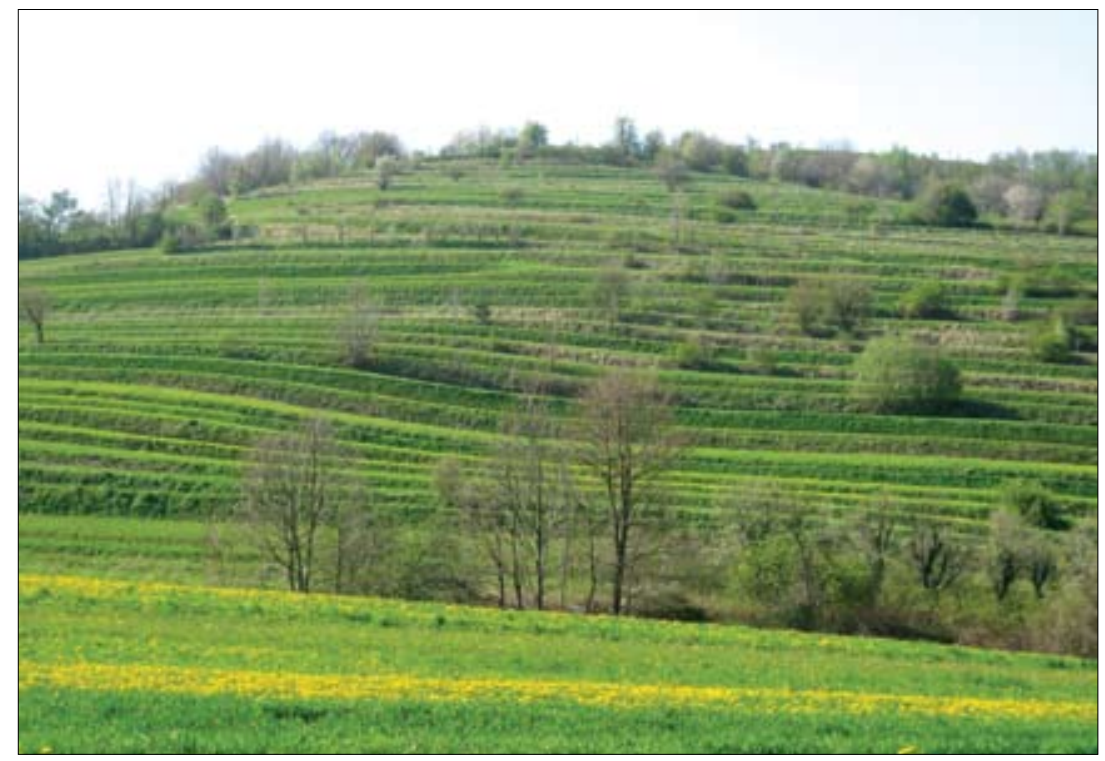

\subsection{Kulturne terase na Dolenjskem}

Kulturne terase so značilne za vzhodni, nižji gričevnat del Dolenjske, kjer se pojavlja poseben tip kulturnih oziroma obdelovalnih teras, ki jih po specifičnih lastnostih imenujemo 
dolenjske terase oziroma dolenjski tip teras. Gre za stare poljedelske terase, ki so močno povezane s poljsko razdelitvijo zemlje na široke ali nepravilne delce in grude. Polja oziroma njive so tukaj nastale na različno dolgih in več metrov širokih terasnih policah. Ponekod so njive razpotegnjene po celotnem pobočju več deset metrov v smeri plastnic in tako ustvarjajo prave terasirane pokrajine. Terasne police so lahko široke od 15 do 20 metrov, ježe teras pa se prilagajajo reliefu, zato so različno visoke, od enega do več metrov. Z nadelavo takih teras so si kmetje ublažili strmino in si na blago nagnjenih pobočjih uredili ravne poljedelske površine.

Posebnost teras je tudi v tem, da je imela običajno vsaka njiva oziroma terasna površina svojega lastnika. Ježe teras so predstavljale meje med parcelami, zato so jih poimenovali kar meje, v Veliki Slevici pa omejki. Kot take so se dedovale iz roda v rod, zato menim, da so zelo stare, izvirajo iz obdobja prvotne kolonizacije. Narejene so bile ročno in so stoletja služile samooskrbnemu poljedelstvu.

Dolenjske terase so posebne tudi zaradi litološke zgradbe. Nastale so na trdnih karbonatnih, večinoma apnenčastih tleh Dinarskokraškega sveta, kar kaže na to, da terasirane pokrajine ne nastajajo le $\mathrm{v}$ pokrajinah mehkih, neodpornih kamnin, kot sta fliš in lapor v slovenskih Obmediteranskih in Obpanonskih pokrajinah. V takih območjih se kulturne terase prilagajajo kraškemu reliefu. Ježe teras se z različnimi višinami prilagajajo plitvim kraškim vrtačam, ki se pojavljajo sredi spontano narejenih terasiranih pobočij. Lep primer takega menjavanja terasiranih pobočij in plitvih kraških vrtač je severno pobočje pod vasjo Šmihel pri Žužemberku. Vse to je lep dokaz, da so bile dolenjske terase narejene ročno in dokaj spontano. Uporabljali so jih za polja, saj je bilo pri blagih nagibih mogoče narediti več metrov široke terasne police; te so ponekod široke med 15 in 20 metrov in zaradi možne strojne obdelave še vedno služijo svojemu namenu. Ježe teras so vse zemljate. Višina jež oziroma brežin se pri starih tradicionalnih terasah po pobočju navzdol spreminja, ker se prilagaja strmini in naklonom pobočij.

Danes njive na terasnih policah zamenjujejo travniki in senožeti kljub širokim terasnim policam, na katerih lahko uporabljajo mehanizacijo. V Veliki Slevici terase celo otežujejo strojno obdelovanje zaradi visokih in neenakomernih omejkov. Proces opuščanja rabe tal na terasah se kaže tudi na ježah teras, ki se zaraščajo z grmovno vegetacijo.

Druga nevarnost, ki grozi terasiranim pokrajinam na Dolenjskem, je suburbanizacija in gradnja počitniških hišic sredi terasiranih pokrajin, ki se s svojo včasih razkošno arhitekturo ne vklapljajo v tradicionalno podeželsko okolje. Zato predlagam, da bi bilo potrebno najlepše primere terasiranih pobočij tudi na Dolenjskem zaščititi kot del kulturne pokrajine iz preteklosti. Žal jih zavod za naravno in kulturno dediščino še ni prepoznal kot dragocen preostanek preteklosti in jih še ni primerno zaščitil.

Med najlepšimi terasiranimi območji na Dolenjskem so tudi vzorčna območja. To so Šmihel pri Žužemberku v Suhi krajini, Dolenje Karteljevo v Dolenjskem podolju in Petelinjek v vzhodnem delu Novomeške kotline. Na splošno pa so kulturne terase pogoste tudi v drugih delih nizke Dolenjske. Terasasto je obdelana zgornja dolina reke Temenice, okolica Sodražice, Velika Slevica, dolina reke Mirne in okolica Šentjanža na Dolenjskem. 
Slika 6: Primer terasiranega pobočja na Dolenjskem, ki bi ga lahko uvrstili na seznam kulturne dediščine zaradi estetske vrednosti; Šmihel pri Žužemberku (foto: H. Križaj Smrdel)

Figure 6: An example of a terraced hillside in Dolenjska. Due to its aesthetic value it could be put on a list of the cultural heritage; Šmihel near Žužemberk (photo: H. Križaj Smrdel)

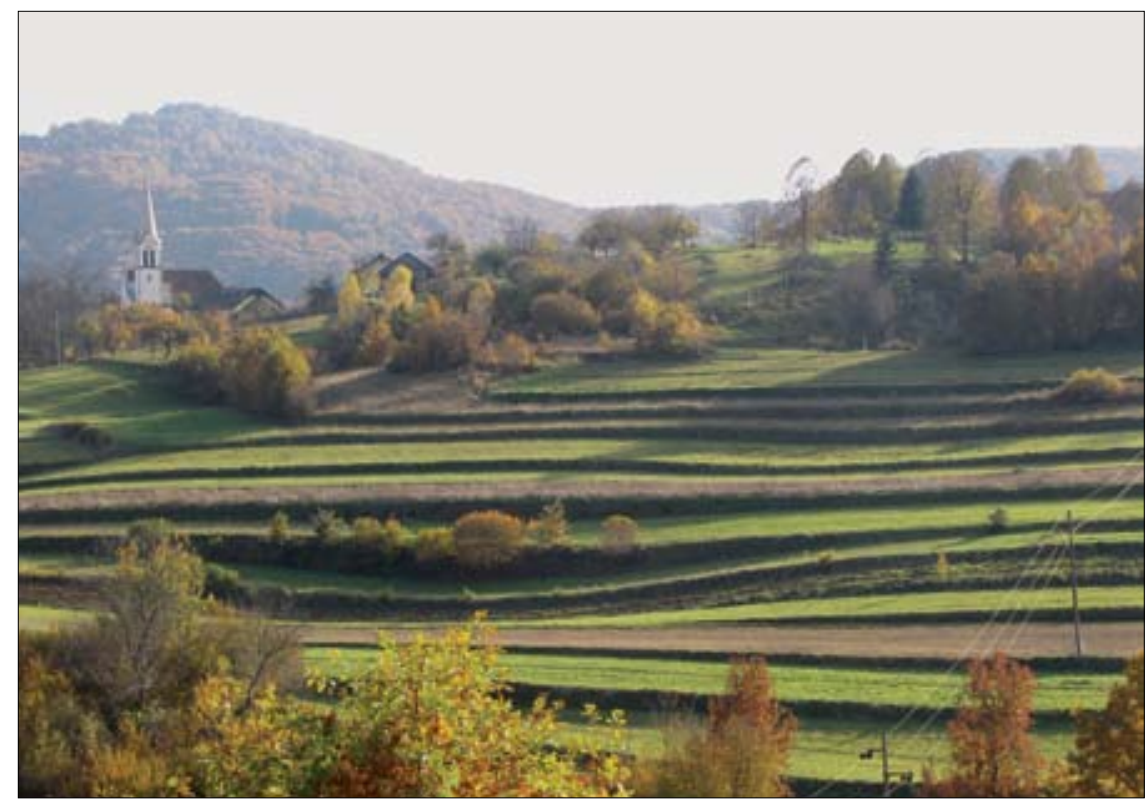

\subsection{Vinogradniške terase v Obpanonski Sloveniji}

Vinogradniške terase v Obpanonski Sloveniji sem preučevala v Bizeljsko-Sremiških goricah, v Halozah in Slovenskih goricah na območju Jeruzalemskih goric. Vinogradniške terase $\mathrm{v}$ omenjenih pokrajinah niso stara, tradicionalna oblika vinogradniškega nasada, niti ne tradicionalen način obdelave zemlje iz preteklosti, kot je to značilno za primorske in dolenjske terase. Predstavljajo nove, sodobne, strojno urejene terase, podobne tako po višini brežine kot po širini terasne police. Brežine so vse zemljate, zatravljene, pri starejših nasadih so zaradi posedanja dobile izrazito konveksno obliko. Terasne police so ozke, široke običajno dva do tri metre, zato so vinogradniški nasadi praviloma vsi enovrstni, s trto na zunanjem robu terasne police, ki z razvojem koreninskega sistema preprečuje erozijo prsti.

Vinogradniške terase so se pojavile šele po drugi svetovni vojni v 60 . letih 20 . st. s spremembo lastniških odnosov zemlje, z velikimi družbeno-gospodarskimi spremembami in z uvedbo mehanizacije v novi socialistični družbi. Veliki terasni nasadi so se izkazali kot najboljša in gospodarsko najučinkovitejša oblika proizvodnje, hkrati pa rešitev iz bede in pomanjkanja, ki so ga ustvarili viničarski odnosi. S komasacijo izredno razdrobljene zemlje so nastali veliki kompleksi terasnih vinogradov, značilni predvsem za Vinorodne Haloze in Slovenske gorice. Prednost terasnih nasadov, ki so jih začeli množično uvajati 
v vseh štajerskih vinorodnih območjih, so bile številne. Začelo se je strojno obdelovanje vinogradov tudi na velikih strminah, terase so preprečile izpiranje in erozijo prsti, zadrževale hranilne snovi in vlago, preprečevale plazove, pospeševale pa tudi zorenje grozdja, ker se je toplota na terasah bolj akumulirala. Na strmih naklonih je bilo na ravnih terasnih policah lažje opravljati tudi druga dela v vinogradu, kot sta obrezovanje in trgatev. Poleg prednosti pa so se sčasoma pokazale tudi pomanjkljivosti terasnih nasadov, kot so slabše izkoriščanje prostora, slabša osončenost, manjša proizvodnja, predraga pridelava, košnja brežin. Po letu 1985 so se zato začeli poleg terasnih nasadov vse bolj uveljavljati vertikalni nasadi, predvsem na bizeljsko-sremiškem območju. Prednost le-teh je večje število trsov na hektar. To pa pomeni večjo proizvodnjo in cenejšo ureditev vinogradov, saj so se terasni nasadi izkazali kot zelo draga oblika priprave vinogradov. Zato strokovnjaki na področju vinogradništva prav v Spodnjem Posavju napovedujejo, da bodo v prihodnje terase kot način vinogradniškega nasada izginile. S procesom opuščanja terasnih nasadov pa se srečujemo tudi v Halozah. Tukaj je predvsem problem denacionalizacija, zaradi katere je veliko terasnih vinogradov opuščenih in neobdelanih.

Kot primer prizadevanja za ohranjanje teras z vinogradi je kraj Podlehnik v Halozah z novim sodobnim vinogradom, opremljenim s t.i. mini terasami in z namakalnim sistemom, delo avstrijskega investitorja. Terasne police so tu ožje, široke le od 1,5 do 1,7 m, brežine pa nižje od 1 do $2 \mathrm{~m}$. Podlehnik v Halozah že na splošno slovi po veliki strmini in reliefni razčlenjenosti. Terasni nasadi so se na strmih haloških gričih izkazali kot najprimernejša oblika vinogradniškega nasada, zato bi bilo škoda, da propadejo. Cilj takih novih terasnih nasadov je tudi ohranjanje kulturne pokrajine in ekološka pridelava.

Slika 7: Novi terasni vinograd z mini terasami in namakalnim sistemom v Podlehniku, Haloze (foto: H. Križaj Smrdel)

Figure 7: A new terraced vineyard with mini terraces and an irrigation system in Podlehnik, Haloze (photo: H. Križaj Smrdel)

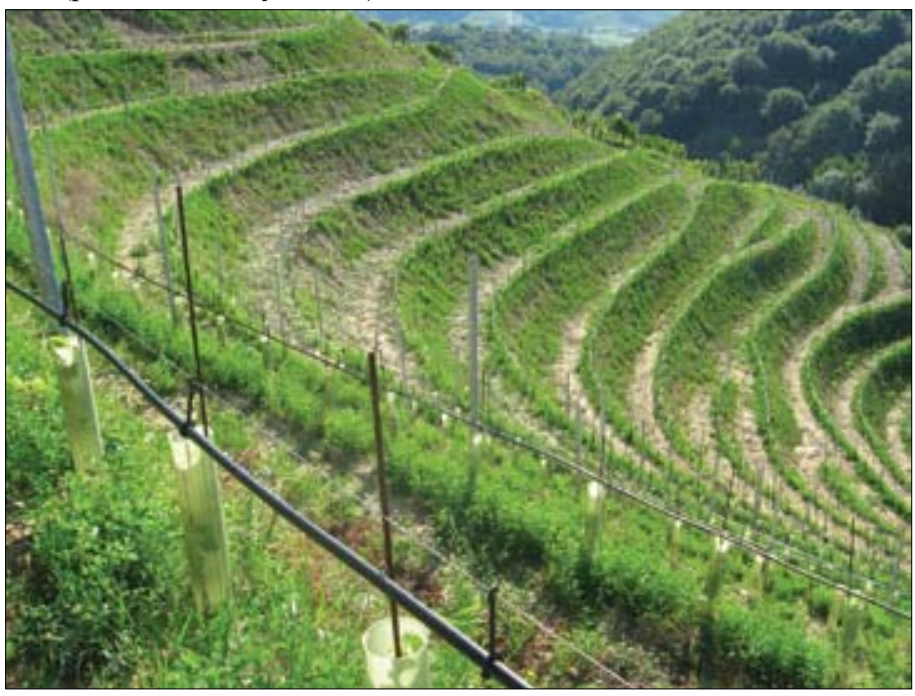


Najlepši in najbolj urejeni terasni vinogradniški nasadi pa vsekakor pripadajo Jeruzalemskim goricam. Po estetski vrednosti izstopa okolica Jeruzalema, ki ohranja terasne vinograde tudi zaradi turizma. Prelepi terasni vinogradi so vzrok za ustanovitev parka Jeruzalem, ki ima nalogo ohranjati kulturno pokrajino in dediščino na tem območju.

\section{POKRAJINSKA KLASIFIKACIJA KULTURNIH TERAS V SLOVENIJI}

$\mathrm{Na}$ osnovi preučevanja kulturnih teras $\mathrm{v}$ številnih slovenskih pokrajinah je bilo ugotovljeno, da je Slovenija terasno precej preoblikovana dežela in da se kulturne terase od pokrajine do pokrajine razlikujejo. Te razlike so posledica naravnih in družbenih danosti posameznih pokrajin in odraz različnih zgodovinskih okoliščin. V večini obravnavanih slovenskih pokrajin kulturne terase predstavljajo staro, tradicionalno obliko kmetijskih melioracij, $\mathrm{v}$ nekaterih pa se pojavijo šele $\mathrm{v}$ drugi polovici 20. st. zato $\mathrm{v}$ osnovi kulturne terase glede na starost razdelimo na stare, ročno grajene tradicionalne terase in nove, sodobne, strojno urejene terase.

Stare, tradicionalne terase so v slovenskih pokrajinah začele nastajati ob prvotni oziroma zgodnji poselitvi kot edina mogoča oblika obdelave zemlje na nagnjenem površju. Sem spadajo vse tradicionalne terase v primorskih pokrajinah, kot so Koprsko primorje, Goriška brda, Vipavska dolina in Brkini. Tukaj so posebni klimatski in pedološki pogoji vzrok, da so bile kulturne terase nujna oblika obdelave zemlje, ki je varovala pred erozijo prsti. Kulturne terase so gradili ročno in uporabljali lokalne gradbene materiale. Tako so na primer $\mathrm{v}$ Koprskem primorju terasne police podprli z opornimi zidovi iz kosov peščenjaka, ki je sestavni del fliša. V notranjem celinskem delu Slovenije najdemo stare, tradicionalne terase na Dolenjskem, kjer so pogoste v vzhodnih dolenjskih pokrajinah, kot so Dolenjsko podolje, Suha krajina, zgornji dolini reke Krke in Temenice ter v Novomeški pokrajini. Zelo podoben tip teras najdemo celo na Notranjskem v Veliki Slevici in okolici Sodražice. Za stare, tradicionalne terase je značilno, da hitro propadajo. To je značilno za Koprsko primorje in Brkine, medtem ko so na Dolenjskem na številnih območjih še lepo ohranjene in obdelane. K temu je prispeval manjši naklon površja in širše, več metrov široke terase police, ki omogočajo strojno obdelavo zemlje.

Povsem drugačen videz pa nam ponujajo nove, sodobne, strojno urejene terase, ki so značilne za slovenske vinorodne pokrajine v Posavju in na Štajerskem. Nastale so v drugi polovici 20. st. $\mathrm{z}$ uvedbo mehanizirane obdelave zemlje. Zaradi enakega strojnega urejanja so si med seboj podobne po širini terasnih polic in po višini brežin ter so namenjene vinogradom. Novi, moderni, strojno urejeni terasni vinogradi so se z uvedbo mehanizacije širili tudi v pokrajine tradicionalnih teras. Zato najdemo danes velike, strojno urejene terasne vinograde tudi v Koprskem primorju in Goriških brdih, kjer popolnoma prevladujejo in ustvarjajo terasni izgled pokrajine. Ta začetna delitev pa je hkrati osnova za izdelavo nove pokrajinske klasifikacije kulturnih teras v Sloveniji. Nastala je na osnovi razlik med tradicionalnimi kulturnimi terasami v različnih slovenskih pokrajinah. Vključuje tudi novo poimenovanje oziroma tipologijo kulturnih teras. 


\section{I. Tradicionalne kulturne terase}

Pri tradicionalnih kulturnih terasah ločimo:

- $\quad$ istrski tip kulturnih teras v Koprskem primorju in Goriških brdih;

- brkinski tip kulturnih teras v Brkinih;

- dolenjski tip kulturnih teras v nizkih dolenjskih pokrajinah in na Notranjskem.

Istrski tip kulturnih teras je značilen za Koprsko primorje oziroma gričevnato obrobje ob slovenski obali in v zaledju; podoben tip najdemo v Goriških brdih in v Vipavski dolini.

Za istrski tip teras je značilna vodoravna terasna ploskev z zidano škarpo, ki jo sestavljajo lepo prilegajoči se kosi peščenjaka. Ta tip teras je nastajal na strmih pobočjih primorskih gričev za varovanje prsti pred erozijo, ki je še posebej močna ob velikih nalivih. Večina takih teras je že opuščenih ali pa propada. Vzrok so ozke terasne police, na katerih ni mogoče strojno obdelovanje, pomanjkanje delovne sile in dovoznih poti.

Slika 8: Istrski tip kulturnih teras; tradicionalen oljčni nasad v Strunjanu (foto: H. Križaj Smrdel) Figure 8: The Istrian type of cultural terraces; a traditional olive tree plantation in Strunjan (photo: H. Križaj Smrdel)

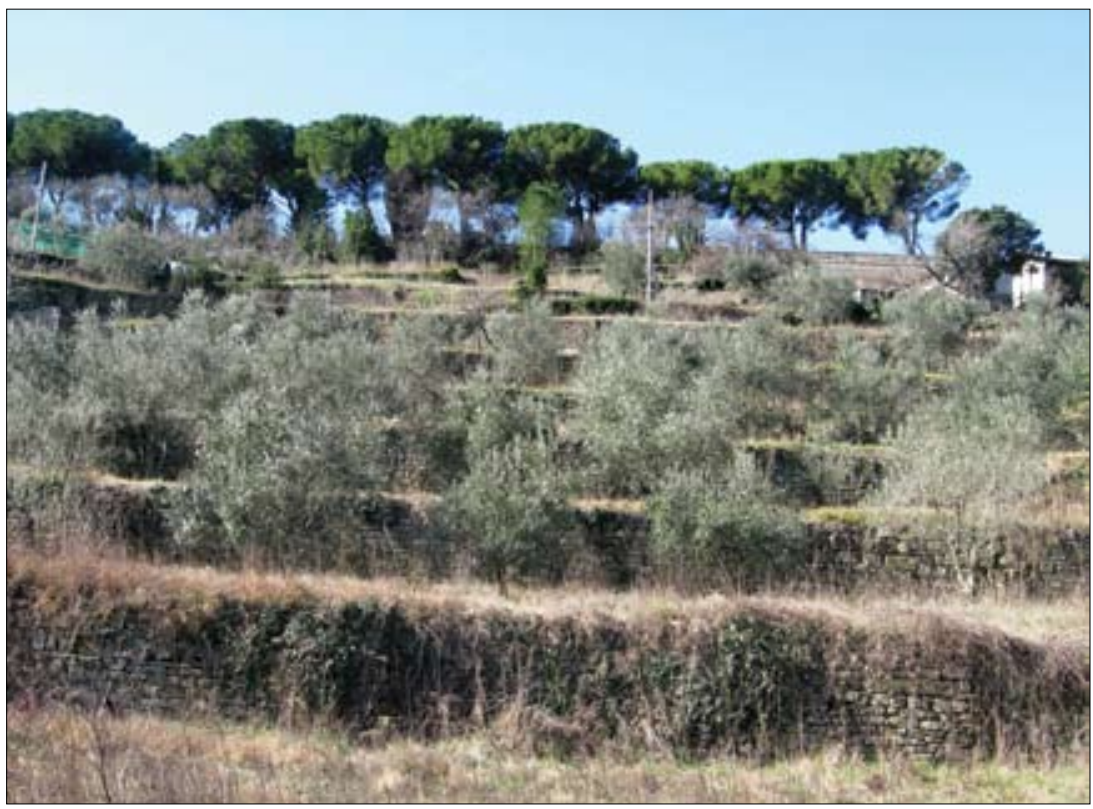

Brkinski tip kulturnih teras se od istrskih razlikuje po tem, da ima zemljate, zatravljene, proti pobočju nagnjene brežine, na katerih je nasajeno sadno drevje. Tega drevja je po koronah, kot pravijo brežinam domačini, je toliko, da dajejo videz sadovnjakov. Med brežinami so več metrov široke vodoravne ali nekoliko navzven nagnjene terasne police, nekoč 
Slika 9: Brkinski tip teras s sadnim drevjem na koronah; vas Javorje (foto: H. Križaj Smrdel) Figure 9: The Brkini type of terraces with fruit trees on the sloping part of the terrace; the village of Javorje (photo: H. Križaj Smrdel)

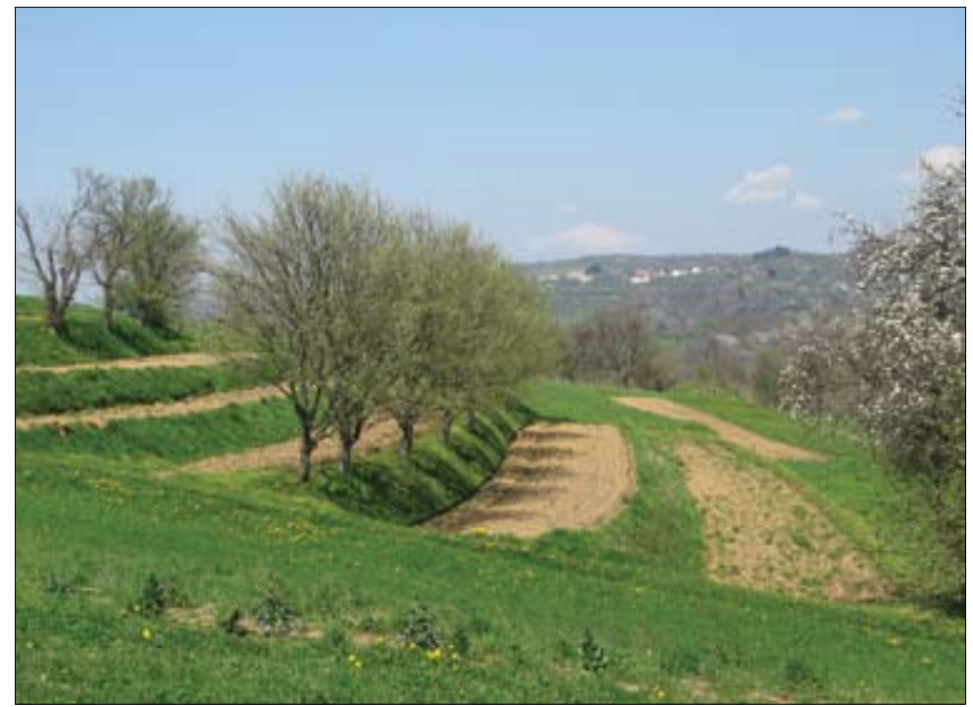

Slika 10: Dolenjski tip kulturnih teras s širokimi njivami na terasah v dolini Temenice. (foto: H. Križaj Smrdel)

Figure 10: The Dolenjska type of cultural terraces with wide fields on the ledges in the valley of Temenica (photo: H. Križaj Smrdel)

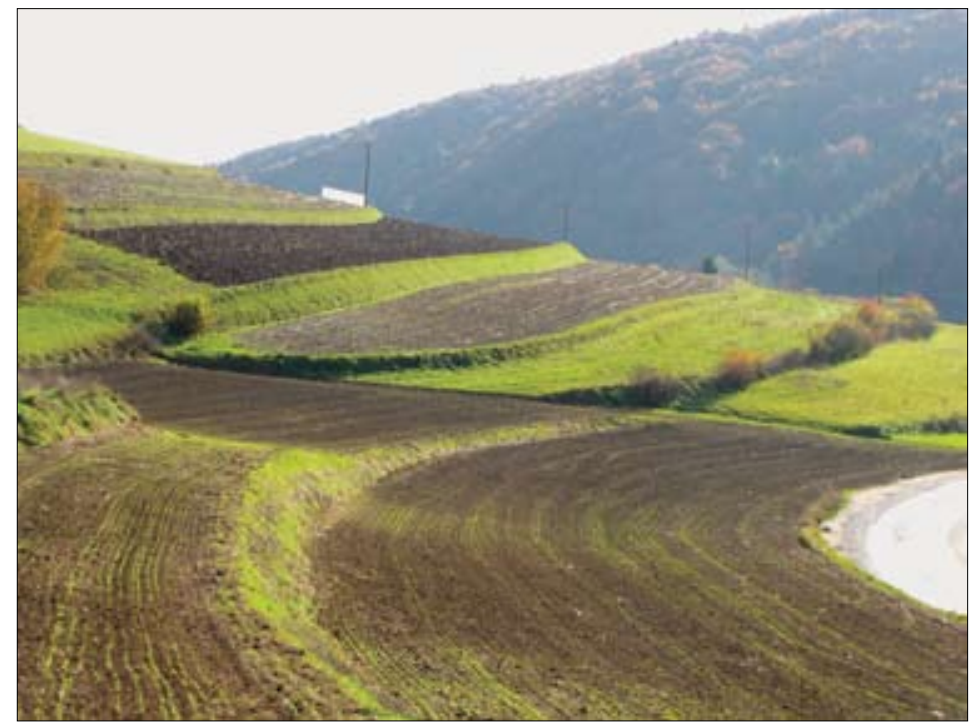


namenjene njivam, danes večinoma travnikom. Strm relief je bil vzrok, da so še danes vsa brkinska pobočja pod slemeni, predvsem na prisojnih pobočjih, lepo terasirana, Brkini pa hkrati pokrajina z najmanj preoblikovanimi tradicionalnimi kulturnimi terasami, ki jih še niso nadomestile nove, sodobne terase. Danes se zaradi opuščanja kmetovanja kulturne terase, predvsem na strmih pobočjih in stran od vasi, zaraščajo in propadajo.

Dolenjski tip kulturnih teras je nastal na blago nagnjenih pobočjih v vzhodnih dolenjskih pokrajinah. Tu so nastale široke poljedelske terase, prave njive, vezane na poljsko razdelitev in niso povsem pravilnih oblik. Zanje so značilne široke vodoravne ali močno navzven nagnjene terasne police $\mathrm{z}$ različno visokimi travnatimi brežinami, ki se prilagajajo reliefu. Terasne police so lahko široke do 20 metrov in se po tem bistveno razlikujejo od ozkih primorskih, vinogradniških teras. Nekoč so služile njivam, ponekod jih še danes obdelujejo, večino njiv pa so kljub temu zamenjali travniki. Zaradi širokih terasnih polic jih je mogoče strojno obdelovati (kositi). Ker tu novo nastalih poljedelskih teras ne najdemo, so te stare terase še vedno vidne in izstopajoče $\mathrm{v}$ pokrajini $\mathrm{v}$ primerjavi s primorskimi pokrajinami, kot sta Koprsko primorje in Goriška brda, kjer so stari, tradicionalni tipi teras že močno zabrisani in jih le še redko vidimo.

\subsection{Sodobne terase}

Pokrajinske razlike pa lahko najdemo tudi pri novih, sodobnih, strojno urejenih terasah. Ker so se prvič pojavile v posavskih in štajerskih vinorodnih območjih, bi jih poimenovala štajerske in posavske vinogradniške terase. Kasneje so jih na enak način uredili tudi v primorskih pokrajinah, predvsem v Goriških brdih in Koprskem primorju. Zaradi modernega, strojnega urejanja so si podobne. Terasne police so dovolj široke za strojno obdelovanje, ježe teras so vse zemljate in zatravljene, kar jih varuje pred erozijo. Razlike med njimi so posledica različne kamninske osnove. Ker so nastale na različnih matičnih osnovah, jih lahko razdelimo na:

- vinogradniške terase na laporju, kamor spadajo posavske in štajerske vinogradniške terase;

- vinogradniške terase na flišu, kamor spadajo primorske vinogradniške terase.

Razlikovali bi jih lahko tudi po številu vrst trt na terasni polici, in sicer na enovrstne, dvovrstne in večvrstne vinogradniške terase. Za Goriška brda so značilne večvrstne vinogradniške terase, to pomeni, da so na terasni polici lahko tri ali štiri vrste trt, posavske vinogradniške terase so večinoma dvovrstne, štajerske vinogradniške terase v Halozah in Slovenskih goricah pa vse enovrstne, s trto na zunanjem robu terasne police. Ker so vse te terase urejene strojno po enakem postopku, so terasne police in ježe enako široke in visoke po celotnem nasadu. Taki novi terasni nasadi zastirajo vpogled v posebnosti in značilnosti starih, tradicionalnih teras, ki počasi izginjajo. V pokrajinah pa je tudi opaziti, da se terasni nasadi na flišnih kamninah širijo, na lapornatih pa krčijo. Vzrok je tudi v erozijski odpornosti kamnin. Na poroznem, erozijsko občutljivem flišu bodo terase vedno prisotne, na lapornatih tleh pa jih bodo vse bolj izpodrivali vertikalni nasadi. Novi, sodobni terasni vinogradniški nasadi najbolj napredujejo v Goriških brdih, ki so zaradi popolne prevlade terasnih vinogradov postala prava terasirana pokrajina. 
Slika 11: Dvovrstne vinogradniške terase na laporju; Pišece na Bizeljskem (foto: H. Križaj Smrdel) Figure 11: Double row vineyard terraces on marl: Pišece in Bizeljsko (photo: H. Križaj Smrdel)

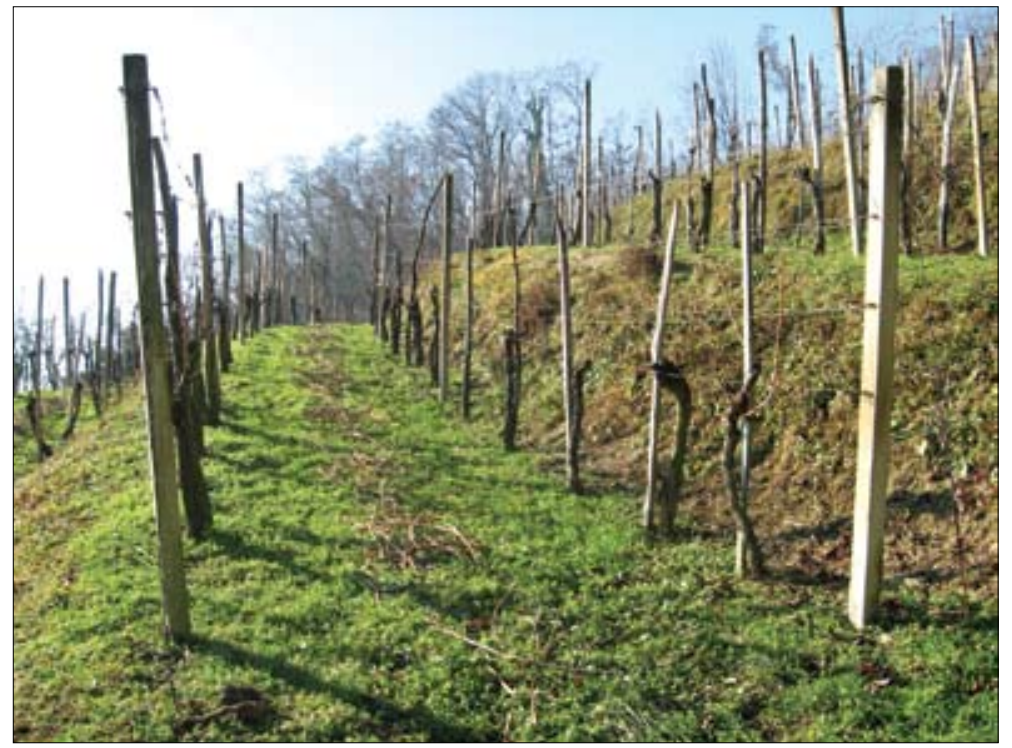

Slika 12: Enovrstne vinogradniške terase na laporju; Slamnjak v Slovenskih goricah (foto: H. Križaj Smrdel)

Figure 12: Single row vineyard terraces on marl; Slamnjak in Slovenske gorice (photo: H. Križaj Smrdel)

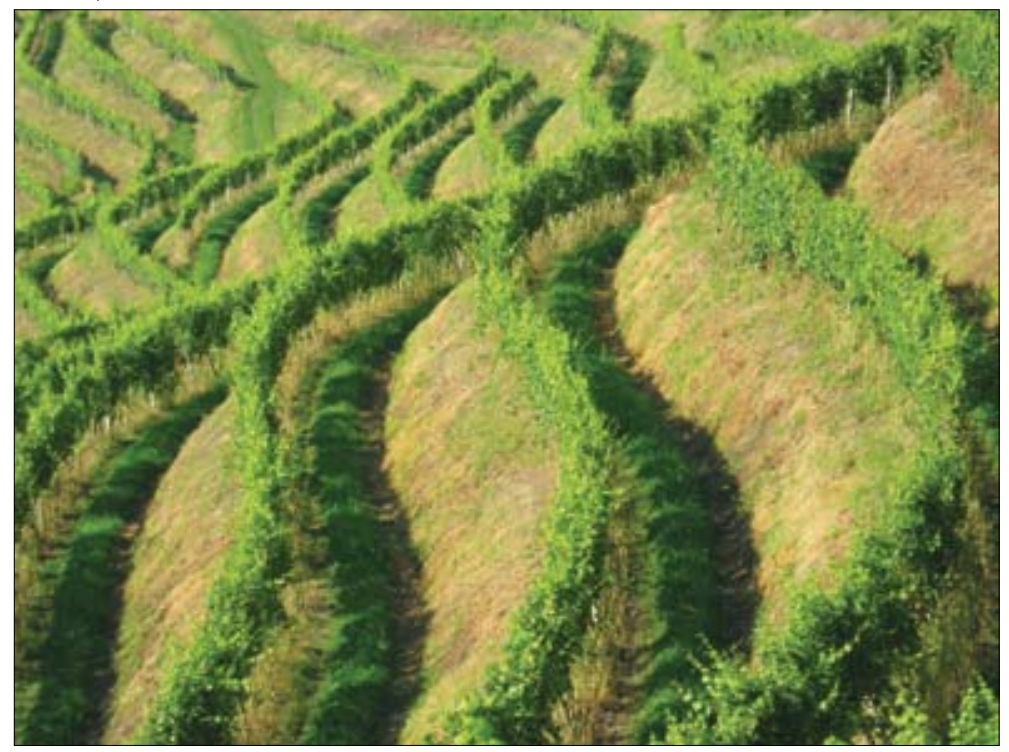


Slika 13: Štirivrstne vinogradniške terase na flišu; Medana v Goriških brdih (foto: H. Križaj Smrdel) Figure 13: Four row vineyard terraces; Medana in Goriška brda (photo: H. Križaj Smrdel)

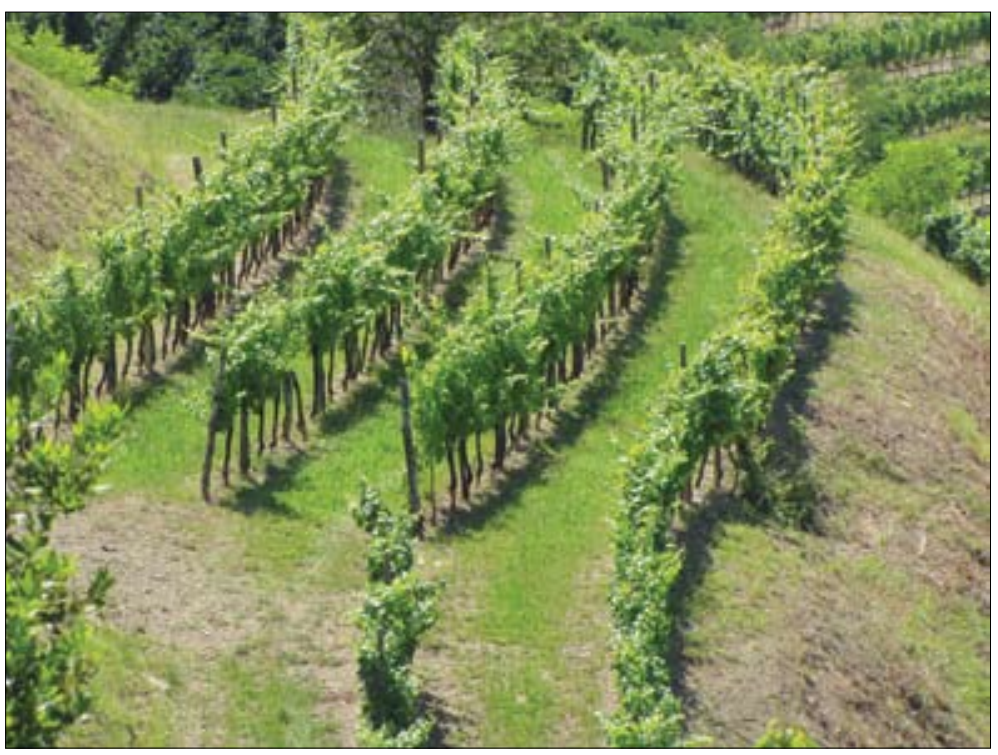

\section{SKLEP}

Kulturne terase so izrazito preoblikovale slovenske gričevnate pokrajine na Primorskem, Dolenjskem in Štajerskem. Različna stopnja družbenogospodarskega in socialnega razvoja ter demografske spremembe vplivajo na spreminjanje terasiranih pokrajin skozi različna zgodovinska obdobja. To se kaže v stagnaciji in upadu terasiranih pokrajin, spet drugje v njihovi rasti in razcvetu. To nihanje pojava je del spreminjajočih se geografskih procesov v pokrajini, katerih del so tudi kulturne terase.

Kulturne terase se v slovenskih pokrajinah razlikujejo po številnih kriterijih. Ti so vezani na njihove osnovne elemente, kot sta terasna ploskev in ježa terase. Ta dva dela teras se namreč prilagajata naravno in družbenogeografskim dejavnikom v posameznih pokrajinah, zato se med seboj v različnih pokrajinah razlikujeta. Posledica tega je različen izgled in pomen teras. To je predvsem značilno za stare, tradicionalne terase, ki jih zaradi pokrajinskih razlik delimo v več tipov, npr. istrski, brkinski in dolenjski tip teras. Stare kulturne terase v Sloveniji večinoma propadajo ali stagnirajo, ponekod jih prerašča gozd, večinoma pa so jih nadomestile nove, sodobne, strojno urejene terase. Čutiti je, da kulturne terase kot pojav v številnih pokrajinah doživljajo krizo. A prepričana sem, da zaradi prevladujočih pozitivnih lastnosti nikoli ne bodo izginile.

Da pa bi ohranili najlepše primere starih, tradicionalnih kulturnih teras pred propadanjem, jih je potrebno zaščititi kot del kulturne dediščine in jih nameniti izobraževanju, turizmu, predvsem pa pridelavi zdrave hrane. Tudi v Sloveniji lahko ustvarimo nove možnosti in novo 
kakovost življenja v terasiranih pokrajinah. Po svetu je veliko primerov, ko terasne pokrajine ne služijo le kmetijstvu. Veliko estetsko vrednost je v njih že prepoznal turizem. Lep primer pri nas za to je Jeruzalem v Slovenskih goricah, ki zaradi privlačnih terasnih vinogradov in vrhunskih vin postaja eden od najbolj prepoznavnih turističnih krajev v Sloveniji.

\section{Viri in literatura}

Arhiv Republike Slovenije: AS176, Franciscejski kataster za Kranjsko. N 157, k. o. Šmihel pri Žužemberku.

Arhiv Republike Slovenije: AS176, Franciscejski kataster za Kranjsko. N 241, k. o. Zagorica pri Novem mestu.

Ažman Momirski, L., Kladnik, D., Komac, B., Petek, F., Repolusk, P. Zorn. M, 2008: Terasirana pokrajina Goriških brd. Založba ZRC, 185 str. Ljubljana.

Belec, B. 1968: Ljutomersko-Ormoške gorice. Založba Obzorja, 290 str. Maribor.

Bračič, V. 1967: Vinorodne Haloze. Založba Obzorja, 250 str. Maribor.

Colnarič, J. 1966: Vpliv vinogradniških teras na mikroklimo rastišča ter rast in razvoj koreninskega sistema vinske trte v Podravskem vinorodnem rajonu. Ljubljana.

Dobršek, T. 1984: Vinogradništvo. Državna založba Slovenije, 318 str. Ljubljana.

Drobnjak, V. 1990: Fizičnogeografski pomen kulturnih teras. V: Primorje. 15. zborovanje slovenskih geografov, Portorož, 24.-27. oktobra 1990. Zveza geografskih društev Slovenije, str. 139-142. Ljubljana.

Drobnjak, V. 1989: Strmina in njena vloga v Krkočanskih hribih: Diplomsko delo. Oddelek za geografijo, Filozofska fakulteta Univerze v Ljubljani. Ljubljana.

Geografija. Učila International, 682 str. Tržič 2001.

Keber, Š. 1971: Brkini. Diplomsko delo. Oddelek za geografijo, Filozofska fakulteta Univerze v Ljubljani. Ljubljana.

Kladnik, D. 1990: Možnosti intenziviranja rabe tal kulturnih teras. V: Primorje. 15. zborovanje slovenskih geografov, 24.-27. oktobra 1990. Zveza geografskih društev Slovenije, str. 143-150. Ljubljana.

Kladnik, D., Natek, M., Pavlin, B., Rejec Brancelj, I., Repolusk, P., Šebenik, I. 1996: Regionalnogeografska monografija Slovenije. Knj. 4: Submediteranska Slovenija. Inštitut za geografijo, 105 str. Ljubljana.

Marušič, I. 1998: Krajine subpanonske regije 3. Ministrstvo za okolje in prostor RS, 91 str. Ljubljana.

Marušič, I. 1998: Krajine primorske regije 5. Ministrstvo za okolje in prostor RS, str 97. Ljubljana.

Melik, A. 1959: Posavska Slovenija. Slovenska matica, 595 str. Ljubljana.

Krajevni leksikon Slovenije. DZS, 638 str. Ljubljana 1995.

Križaj Smrdel, H. 2010: Kulturne terase v slovenskih pokrajinah. Magistrsko delo. Oddelek za geografijo, Filozofska fakulteta Univerze v Ljubljani. Ljubljana.

Petek, F., Urbanc, M. 2004: Franciscejski kataster kot ključ za razumevanje kulturne pokrajine v Sloveniji v 19. stoletju. Acta geographica Slovenica 44, 1, str. 89-112. Ljubljana.

Plut, D. 1976: Koprsko primorje in njegova valorizacija za kmetijstvo in turizem. Magistrsko 